\title{
МУНІЦИПАЛЬНА ПОЛІЦІЯ ЯК ЕЛЕМЕНТ ПРАВООХОРОННОЇ СИСТЕМИ ДЕЯКИХ КРАЇН ЄВРОПИ
}

Голуб М. В.

У статті визначено, що реформування системи органів МВС України спрямовується на вдосконалення та оптимізацію ії структури, організацію діяльності з метою протидіі злочинності, корупціі, своєчасного виявлення та запобігання загрозам внутрішній безпеці України, підвищення рівня захисту прав і свобод громадян, профілактику злочинів і правопорушень. Метою зазначеного процесу $\epsilon$ оста точне перетворення системи МВС України на правоохоронне відомство, яке відповідає сучасним європейським вимогам. 3'ясовано, що у складі поліції охорони порядку німецьких міст, крім служб, на які покладено обов'язок щодо припинення та запобігання правопорушенням, існують підрозділи муніципальної (комунальної) поліції, які здійснюють контроль у сфері санітарії, торгівлі, надання послуг тощо. Доведено, що у країнах Балтії муніципальна поліція виступає в якості елемента правоохоронної системи, на який покладено суттєві повноваження щодо охорони публічного прядку на місцевому рівні, але констатуємо, що муніци пальна поліція і в цій країні виступає в якості допоміжноі структури державної поліції, а їі працівники є итатними працівниками поліціі. Наголошено, що прикладом діяльності муніципальної поліції (поліції самоврядування) Латвійської Республіки є місцева поліція, яка працює в місті Рига. У 1995 році муніципальні поліцейські служби районів міста були об'єднані в єдину муніципальну поліцейську службу Риги. Поліція Ризького самоврядування має складну і комплексну структуру, що складається із штаб-квартири, шести районних відділів і чотирьох спеціалізованих відділів із надання послуг. Зроблено висновок, що для більш ефективного проведення заходів із забезпечення публічного порядку на території України було б доцільно розглянути можливість відновлення функціонування підрозділів муніципальної поліції, яка б сприяла регіональним поліцейськім підрозділам у вирішенні завдань щодо охорони публічного порядку та публічної безпеки. У цій справі доречно використати досвід роботи муніципальної поліції країн Європейського Союзу, який був розглянутий вище, а також $і$ досвід України.

Ключові слова: профілактика правопорушень, охорона публічного порядку, адміністративні правопорушення, муніципальна поліція, соціальна допомога.

В статье определено, что реформирование системы органов МВД Украины направляется на совершенствование и оптимизацию ее структуры, организацию деятельности в целях противодействия преступности, коррупции, своевременного выявления и предотвращения угроз внутренней безопасности Украины, повышение уровня защиты прав и свобод граждан, профилактику преступлений и правонарушений. Целью данного процесса является окончательное превращение системы МВД Украины в правоохранительное ведомство, которое отвечает современным европейским требованиям. Установлено, что в составе полиции охраны порядка немецких городов, кроме служб, на которые возложена обязанность по прекращению и предотвращению правонарушений, существуют подразделения муниципаль-

Голуб М. В., 2019 ной (коммунальной) полиции, осуществляющих контроль в сфере санитарии, торговли, оказания услуг и тому подобное. Доказано, что в странах Балтии муниципальная полиция выступает в качестве элемента правоохранительной системы, на который возложены существенные полномочия по охране общественного порядка на местном уровне, но констатируем, что муниципальная полиция и в этой стране выступает в качестве вспомогательной структуры государственной полиции, а ее работники являются итатными работниками полиции. Отмечено, что примером деятельности муниципальной полиции (милиции самоуправления) Латвийской Республики является местная полиция, которая работает в городе Рига. В 1995 году муниципальные полицейские службы районов города были объединены в единую муниципальную полицейскую службу Риги. Полиция Рижского самоуправления имеет сложную и комплексную структуру, состоящую из штаб-квартиры, шести районных отделов и четырех специализированных отделов по оказанию услуг. Сделан вывод, что для более эффективного проведения мероприятий по обеспечению общественного порядка на территории Украины было бы целесообразно рассмотреть возможность возобновления функционирования подразделений муниципальной полиции, которая бы способствовала региональным полицейским подразделениям в решении задач по охране общественного порядка и общественной безопасности. В этом деле уместно использовать опыт работы муниципальной полиции стран Европейского Союза, который был рассмотрен выше, а также и опыт Украины.

Ключевые слова: профилактика правонарушений, охрана общественного порядка, административные правонарушения, муниципальная полиция, социальная помощь.

The article determines that the reform of the system of the Ministry of Internal Affairs of Ukraine is aimed at improving and optimizing its structure, organizing activities to counter crime, corruption, timely detection and prevention of threats to the internal security of Ukraine, increasing the level of protection of citizens' rights and freedoms, prevention of crimes and offenses. The purpose of this process is the final transformation of the Ministry of Internal Affairs of Ukraine into a law enforcement agency that meets modern European requirements. It has been found out that the police of the German cities are in addition to the services which are responsible for the termination and prevention of offenses, there are units of municipal (communal) police, which control in the sphere of sanitation, trade, provision of services and so on. It is proved that in the Baltic States the municipal police acts as an element of the law enforcement system, which is entrusted with essential powers for the protection of public spinning at the local level, but we state that the municipal police in this country also acts as an auxiliary structure of the state police, and the employees are fulltime police officers. It is emphasized that the local police working in the city of Riga is an example of the activities of the municipal police (self-government police) of the Republic of Latvia. In 1995, the municipal police services of the city districts were merged into a single municipal police service of Riga. The police of Riga self-government has a complex and complex structure 
consisting of the headquarters, six district departments and four specialized departments for rendering services. It was concluded that in order to carry out public order measures more efficiently in Ukraine, it would be advisable to consider restoring the functioning of municipal police units, which would assist regional police units in solving public order and public safety tasks. In this case, it is appropriate to use the experience of the municipal police of the European Union countries discussed above, as well as the experience of Ukraine.

Key words: offense prevention, public order protection, administrative offenses, municipal police, social assistance.

Постановка проблеми. Для виконання поставлених керівництвом держави завдань i, перш за все, подальшого вдосконалення діяльності нової поліції України, остаточного iï перетворення на правоохоронну поліцейську структуру європейського зразка дуже важливо проаналізувати досвід функціонування поліції європейських країн, чітко усвідомлювати, що цей досвід необхідно використовувати у процесі реформування і подальшої діяльності поліції України.

Реформування системи органів МВС України спрямовується на вдосконалення та оптимізацію іï структури, організацію діяльності з метою протидії злочинності, корупції, своєчасного виявлення та запобігання загрозам внутрішній безпеці України, підвищення рівня захисту прав і свобод громадян, профілактику злочинів і правопорушень. Метою зазначеного процесу $\epsilon$ остаточне перетворення системи МВС України на правоохоронне відомство, яке відповідає сучасним європейським вимогам.

Зважаючи на вказане, якісне функціонування нової правоохоронної системи незалежної України вимагає від керівництва МВС подальшого вивчення та впровадження позитивного досвіду діяльності правоохоронних органів у закордонних країнах, зокрема у сфері охорони публічного порядку.

Згідно з розпорядженням Кабінету Міністрів від 22.10.2014 року № 1118-р щодо питання реформування органів внутрішніх справ України, в підготовці якого приймали участь поруч із науковцями і практичні працівники правоохоронних органів, наголошується на тому, що «європейська інтеграція України передбачає забезпечення ефективного функціонування інститутів, які гарантуватимуть верховенство права, додержання прав і свобод людини і громадянина, їх ефективний захист.

У зв'язку із цим одним з ключових завдань $€$ перетворення МВС на цивільний орган європейського зразка» [1].

Реформування правоохоронної системи держави i, в першу чергу, поліції, має бути спрямоване «надання змоги сформувати функціональну та ефективну систему органів внутрішніх справ європейського зразка, якісно вдосконалити правоохоронну діяльність, підвищити ефективність та забезпечити своєчасність реагування на сучасні виклики та загрози» [1].

Стан дослідження. Такі вітчизняні та іноземні науковці, як О.М. Бандурка, В.О. Заросило, Н.В. Камінська, В.Л. Костюк, О.С. Проневич, Ю.І. Римаренко, В.О. Січкар, Е. Томпсон, В.Л. Фільштейн, О.С. Юнін, О.Н. Ярмиш, досліджували європейський досвід діяльності поліції країн ЄС у сфері охорони публічного порядку.

Виклад основного матеріалу. Закордонні дослідники вважають, що першочерговими завданнями поліції $\epsilon$ такі:
1) зміцнення взаємодії галузевих служб і підрозділів поліції між собою, з іншими правоохоронними органами та громадськістю;

2) упровадження стандартів «соціальної відповідальності» органів поліції;

3) подальша спеціалізація персоналу з боротьби 3 конкретними видами правопорушень;

4) підвищення якості професійної підготовки особового складу;

5) оптимізація системи інформаційного забезпечення поліцейських сил; [2-5].

6) упровадження в роботу новітніх технічних засобів

Вважаємо за доцільне розглянути досвід організації охорони публічного порядку на місцевому рівні в окремих країнах Європи шляхом аналізу загальної організації діяльності правоохоронної системи, а також роль муніципальної поліції як складової її частини.

У багатьох європейських країнах забезпечення публічного порядку та публічної безпеки покладається на органи поліції центральної влади, муніципальна поліція в даному випадку відіграє допоміжну функцію, $\epsilon$ органом, який у цій справі надає допомогу центральним органам та органам місцевої влади. Функції муніципальної поліції, обсяг їі повноважень мають певні особливості в різних європейських країнах.

Так, правоохоронна система в Німеччині складається із двох рівнів: федерального і суб'єктів федерації (земель). В одних землях (Нижня Саксонія, Північна Рейн-Вестфалія, Саарланд, Шлезвінг-Гольштейн) поліція загалом $€$ державною, в інших (Баварія, Гессен) - це фактично муніципальна структура [6]. Взаємодія федеральної поліції та поліції земель здійснюється через укладення угод між MBC Німеччини і $M B C$ земель, а також через постійну раду міністрів внутрішніх справ земель [6].

У складі поліції охорони порядку німецьких міст, крім служб, на які покладено обов'язок щодо припинення та запобігання правопорушенням, існують підрозділи муніципальної (комунальної) поліції, які здійснюють контроль у сфері санітарії, торгівлі, надання послуг тощо. Заслуговує уваги із практичної та наукової точок зору той факт, що співробітник поліції охорони порядку повинен на початку служби кілька років прослужити в поліції готовності (підрозділ федеральної поліції) [7]. Вважаємо, що такий підхід сприяє підвищенню ефективності діяльності поліції охорони порядку, оскільки на службу до цього підрозділу приходять працівники вже з досвідом практичної роботи.

Поліція охорони в Німеччині здійснює загальну охорону публічного порядку. Незважаючи на те, що в кожній із земель діє своє законодавство та відомчі приписи, які регулюють діяльність поліції, напрямки діяльності охоронної поліції в цілому у всіх землях однакові. Зважаючи на широке коло повноважень підрозділів поліції охорони, зазначеним підрозділам допомагають підрозділи комунальної поліції, які більш орієнтовані на контрольні функції щодо виконання правил, встановлених адміністрацією конкретного регіону. Таким чином, можна дійти висновку, що в Німеччині питанням охорони публічного порядку як на загальному, так і на регіональному рівні приділяється значна увага. Наведений висновок зумовлений наявністю надзвичайно широких повноважень - від безпосередньої охорони правопо- 
рядку в публічних місцях до контролю за виконанням місцевих правил поведінки в різних сферах.

Компетенція муніципальної поліції таких європейських країн, як Великобританія та Франція, включає в себе, перш за все, функції боротьби зі злочинністю та підтримання публічного порядку.

Муніципальною поліцією Франції керує місцева влада в особі мера міста. Під час виконання своїх повноважень щодо питань охорони публічного порядку на території міст, селищ тощо муніципальна поліція підконтрольна та підзвітна владі місцевого самоврядування. Муніципальна поліція Франції відповідає за вирішення питань щодо :

- забезпечення публічного порядку та публічної без-

пеки, в тому числі під час проведення масових заходів; правильного застосування нормативних актів на відповідній території;

- контролю і регулювання, за необхідності, дорожнього руху;

- припинення порушень правил дорожнього руху; фіксації протиправних дій та повідомлення про злочини;

- припинення протиправних дій та передачі матеріалів і затриманих осіб до підрозділів національної поліції; - надання допомоги населенню в разі виникнення аварій, катастроф, стихійних лих;

здійснення контролю за дотриманням правил благоустрою на території міста, селища, правил паркування, правил тримання домашніх тварин, а також санітарних вимог щодо безпечного рівня шуму [8].

Закон Великобританії «Про поліцію» визначає особливості функціонування місцевої поліції щодо охорони публічного порядку, а саме:

- поліція широко використовує технічні та електронні засоби спостереження за районами, де розташовані торговельні та розважальні заклади, що допомагає швидко реагувати на порушення публічного порядку;

поліцейські сили використовують різні методи взаємодії із власниками розважальних закладів. Наприклад, із метою зменшення фактів вживання та продажу наркотичних засобів поліцейські разом із власниками закладів запроваджують обов'язковий обшук відвідувачів;

поліція має право заходити у приміщення будьякого бару, кафе, клубу чи ресторану в будь-який час;

- має право зачиняти будь-який публічний чи розважальний заклад, якщо він сприяє порушенням громадського порядку, якщо $є$ скарги громадян, що живуть у районі, де розташований цей заклад, або якщо $\epsilon$ підстави вважати, що цей заклад $є$ центром кримінальної активності;

- поліція підтримує тісний зв'язок із мешканцями тих регіонів, де найчастіше можуть виникати порушення публічного порядку;

поліцейські можуть отримувати від власників будинків інформацію про те, що вони, наприклад, виїжджають у відпустку, з метою використання цієі інформації під час здійснення патрулювання та запобігання крадіжкам.

У районах міст та в сільській місцевості створюються так звані «команди безпечного сусідства» [9].

Особливість охорони публічного порядку на місцевому рівні у Великобританії полягає в тому, що кожен конкретний поліцейській підрозділ місцевої поліції несе відповідальність за стан правопорядку в межах закріпленої за цим підрозділом території.

Якщо розглянути організацію роботи муніципальної поліції Італії, Бельгії, Нідерландів, то ми бачимо, що в цих країнах муніципальна поліція відіграє допоміжну роль - виконує функції із забезпечення публічного порядку i не наділена повноваженнями розслідувати злочини.

Мають свою специфіку діяльності підрозділи муніципальної поліції країн Балтії, де все більше охорону публічного порядку на місцевому рівні стала здійснювати саме муніципальна поліція. Організація роботи цих підрозділів полягає не тільки в забезпеченні публічного порядку, а й у вирішенні інших завдань. Так, роботу муніципальної поліції Естонської Республіки можна розглянути на прикладі функціонування місцевої поліції міста Таллінн, яка бере участь у здійсненні охорони публічного порядку на території міста та контролює виконання положень місцевих нормативно-правових актів. Зокрема, до іï завдань належать: охорона власності міста, перевірка проїзних квитків у міському громадському транспорті, здійснення провадження з порушень правил паркування автомобілів, здійснення контролю за утриманням домашніх кішок і собак, здійснення контролю за діяльністю таксі на муніципальній території, тимчасове регулювання руху транспорту в разі порушення руху на дорогах [10].

Згідно зі статтею 15 Закону Латвійської Республіки «Про поліцію» від 04.06.1991 року (редакція від 18.10.2018 року) визначено, що муніципальна поліція $\epsilon$ структурною складовою частиною національної поліції Латвії поряд із державною та портовою поліцією. Муніципальна поліція здійснює свої повноваження на відповідній території, а також входить до складу відповідного муніципалітету і взаємодіє з державною поліцією [11]. У статті 19 цього Закону закріплюється можливість відповідного органу місцевого самоврядування визначати кількість співробітників муніципальної поліції [11].

Прикладом діяльності муніципальної поліції (поліції самоврядування) Латвійської Республіки $є$ місцева поліція, яка працює в місті Рига. У 1995 році муніципальні поліцейські служби районів міста були об'єднані в єдину муніципальну поліцейську службу Риги. Поліція Ризького самоврядування має складну і комплексну структуру, що складається із штаб-квартири, шести районних відділів і чотирьох спеціалізованих відділів із надання послуг. Поліція Ризького самоврядування $\epsilon$ підрозділом Ризької думи, проте ії діяльність регулюється Законом «Про поліцію» Латвійської Республіки [11] та Положенням про Ризьку муніципальну поліцію від 1 червня 2003 р. № 75 [12].

Основними напрямками діяльності муніципальної поліції міста Рига $є$ :

контроль за виконанням затверджених Ризькою думою обов'язкових правил, постанов i покарання за ïх недотримання; обслуговування викликів у цілодобовому режимі;

розгляд заяв, пропозицій та скарг фізичних і юридичних осіб;

розподіл викликів, отриманих за телефоном «гарячої лінії», між державною та муніципальною поліцією для оперативного реагування на порушення публічного порядку;

- патрулювання в найбільш важливих публічних місцях Риги 
- забезпечення публічного порядку під час пікетів, мітингів, комерційних та спортивних заходів;

- доставка до медичних установ або до місця проживання осіб, які втратили здатність пересуватися самостійно під впливом алкоголю або наркотичних речовин; - примусова доставка осіб за рішенням суду або прокуратури;

- доставка визнаних недієздатними осіб до психіатра, якщо зазначені особи представляють загрозу для власного здоров'я та життя оточуючих;

- забезпечення безпеки жителів міста в разі аварій, катастроф, стихійних лих та інших надзвичайних ситуацій, обстеження небезпечних об'єктів, складання планів евакуації, розселення осіб, які постраждали від нещасних випадків, та надання їм першої соціальної допомоги тощо.

У структурі муніципальної поліції Риги діють департамент охорони публічного порядку (патрулювання), адміністративний департамент (профілактика, провадження в справах про адміністративні правопорушення), департамент контролю та безпеки (оброблення екстрених викликів, контроль за системою відеоспостереження), секція цивільної оборони та спасіння на воді, секція профілактики правопорушень серед неповнолітніх, секція туризму, яка відповідає за зв'язок із туристичними компаніями, допомогу іноземним туристам, управління дорожньої поліції [13].

Отже, у країнах Балтії муніципальна поліція виступає в якості елемента правоохоронної системи, на який покладено суттєві повноваження щодо охорони публічного прядку на місцевому рівні, але констатуємо, що муніципальна поліція і в цій країні виступає в якості допоміжної структури державної поліції, а їі працівники $\epsilon$ штатними працівниками поліції.

Що стосується створення та функціонування муніципальної поліції в Україні, то наша держава має такий досвід. Підрозділи муніципальної міліції були створені в деяких областях, у тому числі Харківській, Луцькій та Тернопільській. Так, виконавчий комітет Харківської міської ради народних депутатів рішенням від 14 лютого 1996 р. № 63 підтримав пропозицію про створення міського підрозділу місцевої міліції. У зв'язку із зазначеною пропозицією наказом УМВС України в Харківській області від 23 лютого 1996 р. № 124 було затверджено штат окремого батальйону патрульно-постової служби при Харківському міському управлінні УМВС України в Харківській області, який проіснував до 2003 року [14, с. 74-76]. В обов'язки цього підрозділу входило: забезпечення публічного порядку під час проведення масових заходів, патрулювання вулиць, проведення рейдів у громадському транспорті, охорона об'єктів міста.

Висновки. Виходячи з вищевикладеного, ми робимо висновок, що для більш ефективного проведення заходів із забезпечення публічного порядку на території України було б доцільно розглянути можливість відновлення функціонування підрозділів муніципальної поліції, яка б сприяла регіональним поліцейськім під- розділам у вирішенні завдань щодо охорони публічного порядку та публічної безпеки. У цій справі доречно використати досвід роботи муніципальної поліції країн Європейського Союзу, який був розглянутий вище, а також і досвід України.

\section{Література}

1. Питання реформування органів внутрішніх справ України : розпорядження Кабінету Міністрів України від 22 жовтня 2014 р. № 1118-p. URL : https://zakon.rada.gov. ua/go/1118- 2014-p.

2. Рекомендації з питань поліцейської діяльності в багатонаціональному суспільстві : Верховний комісар ОБСЄ у справах національних меншин, 2006 p. URL : http://www. osce.org/uk/hcnm/32236.

3. Ozdemir Habib. Strategic Police Management for Effective Crime Deterrence in New York City: Working Paper. NY, 2001. № 30. 30 p.

4. Thompson Elizabeth (Lisa) Effective Police Communication. URL : http://www.ehow.com/ facts_7443346_effective-police-communication.html.

5. Metropolitan Police Service Corporate Social Responsibility Strategy 2010-2013. URL : http://www.met. police.uk/about/ documents/csr_strategy.pdf.

6. Links zu den Internetauftritten der Polizeien und polizeilicher Einrichtungen der Länder und des Bundes: офіційний Інтернет-портал поліції земель Німеччини. URL : http://www.polizei.de/Polizei/DE/Home/ homepage_ node.html?_nnn=true.

7. Полиция Германии: Еженедельная газета ГУ МВД РФ по г. Москве. 31 авг. 2011 г. № 34(222). URL : http:// petrovka-38.com/nums/6891.htm.

8. Поліція Франції: Policing OnLine Information System. URL : http://polis.osce.org/countries/details?item_id=24.

9. Police Act 1996: офіційний сайт законодавства Великобританії. URL : http://www.legislation.gov.uk/ ukpga/ 1996/16/contents.

10. Tallinna Munitsipaalpolitsei Amet: офіційний сайт Департаменту муніципальної поліції міста Таллінн. URL : http:/ / tallinn.munitsipaalpolitsei.ee.

11. Про поліцію : Закон Латвійської Республіки: від 04.06.1991. URL : m.likumi.lv/doc.php?id=67957.

12. Rīgas pašvaldības policijas nolikums: офіційний сайт муніципалітету міста Рига. URL : http://www.riga. Iv/ru/ Systems/Edc/Document. aspx?documentGUID=27eed42bbddf-40f5-8181-906715f8a31d.

13. Rīgas Pašvaldības policija: офіційний сайт муніципальної поліції міста Рига. URL : http://rpp.riga.lv/index. php/en/ about-us/2012-02-10-17-19-00.

14. Сергєєв А.В. Організаційно-правові засади діяльності підрозділів місцевої міліції щодо охорони громадського порядку : дис. канд. юрид. наук : спец. 12.00.07. Харків, 2004. 216 c.

Голуб М. В., кандидат юридичних наук, доцент кафедри правоохоронної діяльності та поліціїстики факультету № 6 Харківського національного університету внутрішніх справ 